\title{
Nothing is New Under the Sun Featuring: The Chief in Ghana's Politics
}

\author{
Ernest Kwadwo Kyere ${ }^{1}$ \\ School of Law, University of Cape Coast, PMB, Cape Coast, Central Region. Ghana.
}

\begin{abstract}
FOREWORD
As is evident in this paper, chieftaincy is one of the oldest institutions of African states in general and Ghana in particular. Right from precolonial times to colonial days and postcolonial times, the chieftaincy institution has aided and continues to aid the seamless administration of the Ghanaian nation-state. Our chiefs' palaces are still the first point of call for politicians when they tour the country either to campaign or to commission a government project. This I believe is so because chiefs have remained efficient liaisons between politicians and the citizenry. This in my considered opinion is why Ernest K. Kyere who is already well set on the path of carving an enviable niche for himself in critical scholarship (judging from his many published articles on diverse topics) argues that the chief cannot continue to be resigned to the fringes of mainstream politics in Ghana today. As he embarks upon the painstaking task of asking some really tough questions about the role of the chief on the stage of modern-day Ghanaian politics and tries to tease out answers to these, we could all, aside admiring and applauding his prowess, do more to have a national conversation on the best way forward for chieftaincy and how same could help deliver good governance to the good people of Ghana. I respectfully urge us all to make time to read this article with an open mind and to join the very important conversation broached herein.
\end{abstract}

Obrempon Hima-Dekyi XIV Obrempon XIV (Overlord of Dixcove)

\begin{abstract}
The conceptualization of Chiefs as instruments of politics is not a new concept. Over the last two decades or so, there has been a vile practice perpetuating in Ghana's politics where chiefs are being used by politicians to gain political advantage or solicit for votes. The first trace of this political game can be tracked to the era of indirect rule. For much of the $19^{\text {th }}$ century, British exercised its dominion over the people of Ghana through their chiefs. Indirect rule could be comprehended as the idea to use existing customary structures and traditions as canals for creating rules and regulations, while British officers operated behind the scenes to gain the approval and support of Ghanaians ${ }^{2}$. The practice today is not so dissimilar from colonial times. The outstanding distinction is bared in the fact that today, politicians are not trying to hide their diplomatic control over Chiefs.
\end{abstract}

Keywords: the chief, chieftaincy institution, indirect rule, active politics, partisan politics

DOI: $10.7176 / \mathrm{JLPG} / 115-10$

Publication date: November $30^{\text {th }} 2021$

\subsection{Introduction}

"Nothing is new under the Sun" foretells the neo-political role of a chief in Ghana. It emphasizes the reinstitutionalization of the chieftaincy institution impelled from Ghana's play of putrid politics. The author employs the qualitative external desktop research method in gathering information while analytically tracing the involvement of chiefs in politics from the last past ten years. He further relies on the combination of primary and secondary source of information as literature to advance his arguments. Ghana's politics has been a game of unscrupulous plots and schemes, where the best player (or politician) wins. Such political subversions have unwarily creeped into the chieftaincy institution, leaving doubt to the plausibility of Article 276. The question raised is, how can a chief be asked to sit out in active politics when politics is not just a mode of governance but the Ghanaian person's way of life?

The article in its early sections, descriptively narrates the life of the chief in pre-historic and modern times. It considers the nature of the chief's office while highlighting his role in the $21^{\text {st }}$ century. In the light of principles of equality of all men and democracy, the article articulates the liabilities of the chief in the discharge of his duties. The article is climaxed by an illustration of the current state of Ghana's politics and how chiefs are involved in its operation. It further discusses some wrongs attributed to the chieftaincy institution. By way of conclusion, it suggests ways of improving chieftaincy in Ghana.

It is said that life is only, but, a reoccurrence of past events and there is nothing new under the sun. Dating back from the $19^{\text {th }}$ century, the chieftaincy institution has proven itself to be the most sturdy and resilient

\footnotetext{
${ }^{1} \mathrm{He}$ is an undergraduate LLB student at the University of Cape Coast with some online published articles (modern Ghana and Ghana web) to his credit.

${ }^{2}$ England's Indirect Rule in its African countries. American Historical Association. Available at https://www.historians.org/teaching-andlearning -in-the-digital-age/England's-indirect-rule-in-its-African-countries.
} 
institution to have survived colonial times to this date ${ }^{1}$. The foundations and the walls of the institution are so strong that it has been said if the chieftaincy institution did not die in the hands of the colonial and post-colonial administrations, nothing can kill it. It was there when the Europeans first arrived at the shores of the Coast. It received them, co-operated with them and at some point, was ruled by them. It saw through the various transition of governments: from the military coups to democratic governance and all its interposes. If there is any embodiment of history, culture and knowledge, it can be found in the chieftaincy institution.

\section{Tenets of Chieftaincy}

The word "chief" according to Adjaye and Misawa (2006) is a creation of the colonial administration. It is said to have been coined in an attempt to define the position of African traditional leaders in the indirect rule system. ${ }^{2}$ It was to this effect, Rathbone (2000) contended in "The Fate of Natural Rulers under Nationalist Governments", that in order for the British government not to contradict the name "King" which was a reserve of the British monarch, suggested the name "chief" so as to ensure that the powers of the African traditional leaders could not be seen to be equated to that of the British monarch ${ }^{3}$. Chieftaincy institution in here, refers to an extensive group of traditional leaders consisting of the paramount chiefs, queen mothers, sub chiefs, linguists as well as any designated positions whose occupiers have authority exercisable over a group of people within their domain. ${ }^{4}$ Arhin (1985) has defined a chief as a "person elected or selected in accordance with customary usage and recognized by the government to wield authority and perform functions derived from tradition or assigned by central government within specified areas. ${ }^{5}$ "The foremost distinctness of the definition is that it takes into recognizance the dual task-role of the chief. That is, the chief performs both customary functions and statutory or governmental duties. The definition would also suggest that the validity of a person as a chief is reliant on the recognition given by the government. This is, however, not the case in Ghana. Article 277 of the 1992 Constitution of Ghana ${ }^{6}$ defines a chief as, "a person who hailing from the appropriate family and lineage, has been validly nominated, elected or selected and enstooled, enskinned or installed as a chief or queen mother in accordance with the relevant customary law and usage. Article 277 is by far the most comprehensive definition of a chief. The definition presupposes the proof of four criteria ${ }^{7}$ before one would be recognized as a Chief in Ghana. The requirements to be satisfied include that one;

He must be a Person: By this, the law is referring to a "natural person" - a human being naturally born. ${ }^{8}$ This implies a person born of a man and a woman. It does not include an artificial person or a juridical person, which may be a corporate body, an institution or an organization.

Hailing from the appropriate family and lineage: Under Ghanaian customary law, not everyone could become a chief. The person must have royal blood and consequently, be a member of the royal family. The Ghanaian family is a combination of different branches of families, the person to be named chief, must of necessity hail from the family where the royal lineage begins and falls. In the case of Brobbey and others $v$ $\boldsymbol{K} \boldsymbol{w a k u},{ }^{9}$ a validly nominated, elected and installed chief, from the Mampong stool, was alleged to be a descendant of a Grunshie slave. Hailing from a Grunshie ancestor, the traditional elders of the stool sought his immediate destoolment. The court held that though he was a member of the royal family, he did not hail from the "appropriate" family. He was subsequently, destooled.

Validly nominated, elected or selected and enstooled, enskinned or installed: The procedure for the enstoolment or installation of a chief differs from community to community. Customarily, only the kingmakers have the right to enstool a chief upon vacancy, either arising from the destoolment of a chief, abdication or any of such other acts or events, capable of making the stool vacant. The queen mother, however, reserved the exclusive responsibility for the nomination of chiefs, subject to the approval of the kingmakers. The case of Republic v Boateng; Ex parte Adu-Gyamfi II', gave patronage to this practice when it held that "the queen mother was entitled by custom to nominate three candidates from the royal family". Where the queen mother's candidate was not acceptable to the people, she must find another candidate. Meanwhile, the stool would remain vacant.

\footnotetext{
${ }^{1}$ Boateng, Kwabena (2020). Chieftaincy: An Anachronistic Institution within a Democratic dispensation? The Case of a Traditional Political System in Ghana.

2 Joseph K. Adjaye and Buba Misawa, "Chieftaincy at the confluence of Tradition: Transforming African Rulership in Ghana and Nigeria", International Third World Studies Journal and Review, vol 17, (2006): p. 1

${ }^{3}$ Rathbone, "Kwame Nkrumah and the Chiefs: The Fate of Natural Rulers under Nationalist Governments", Transactions of the Royal Historical Society, vol 10, (2000): p. 45

${ }^{4}$ Knierzinger Johannes, "Chieftaincy and Development in Ghana: From Political Intermediaries to Neotraditional development", Working papers of the Department of Anthropology and African Studies of Johannes Guttenberg, 2011, p. 6.

${ }^{5}$ Arhin K (1985). Traditional Rule in Ghana: Past and Present. Accra, Sedco Publishing.

${ }^{6}$ The 1992 Constitution of the Republic of Ghana.

${ }^{7}$ These four criterions are termed as the tenets of chieftaincy.

${ }^{8}$ Black's Law Dictionary, $2^{\text {nd }}$ Edition http://thelawdictionary.org/natural-person/

${ }^{9}$ [1995-96] 1 GLR 125

${ }^{10}$ [1972] 1 GLR 317
} 
In accordance with relevant customary law and usage: Traditionally, the appointment of a person as chief was wholly based on the applicable customs of a particular community ${ }^{1}$. What is referred to as "relevant customary law" is subjective upon the custom and practice of the particular community. It entails the rituals and practices needed to validate the nomination and appointment of a person as a chief. Aikins JSC ${ }^{2}$ notes that, "though the swearing of the oath of allegiance and installation are essential formalities in the chief making process, yet the mere fact that there has been an election, installation and swearing of oath of allegiance will not, of itself, validate an invalid nomination, election and installation of a person which is not made in accordance with the relevant customary law".

\section{Historic travel of the Chief's life in Pre-colonial, Colonial and Post-colonial times}

The understanding and conception of the chief has continuously transformed over the years. In pre-colonial times, the chief was conceived as an epitome of wisdom and counsel. His words were final and binding, and he was often described as anachronistic (Boateng 2020). ${ }^{3}$ K.A Busia, however, contradicts this view. He asserts that the custom and usage by which the chief came to power placed some checks on his powers. As the supreme overlord of his community, his office was interwoven between the political, social, religious, cultural and economic spheres of his community. K.A Busia averred that the chief in pre-colonial times occupied a religious office. As such he acted as the chief priest of his people and would offer sacrifices and libations on behalf of his people ${ }^{4}$. Arhin (1985), on the other hand, believed that the chief's office was a purely political one. He combined the duties of the three arms of government. As a member of the legislative body, the chief was responsible for making laws throughout his own region, in consultation with his traditional elders. As the head of his judiciary body, he settled dispute that arose between his people ranging from civil suits to criminal actions through native customs and laws. As the head of the executive, the chief was the commander of the military and was responsible for the socio-economic development of his community.

In colonial times, the chief enjoyed considerable amount of power but by the crush of the Bond of 1844, the Supreme Court Ordinance of 1866, and the Native Court Ordinance of 1954, most of their powers had been seceded away. The chief's role in colonial times was carried out through the indirect rule system. During the era of Indirect Rule, the British operated using local decentralized structures. The practice was to use already existing native administrative institutions to ensure that there was local participation. Eminent chiefs were made key players in the administration of local government through the maintenance of law and order, collection of taxes, settlement of disputes and promotion of socio-economic development ${ }^{5}$. The inauguration of Kwame Nkrumah as president in 1960 brought a fall to their status and privilege. His decision to reduce their status stemmed from their opposition against his political party in its early days. Those chiefs who supported him had their status lifted to paramount chiefs. Under the Nkrumah government (1954), chiefs were excluded from the local councils. By 1958, he had their courts obliterated. The decline in the chieftaincy institution was most harshly felt under Nkrumah's government than under the British government. Though it was under the colonial government that the chieftaincy institution became unpopular due to the advent of indirect rule, Nkrumah retained the constitutional power of the colonial government to recognize chiefs, that is, to make and unmake chiefs and put himself in charge of stool lands ${ }^{6}$. It was from here that the practice of lands being vested in a President begun. Their power was, however, shortly regained after he was overthrown in 1966 by the National Liberation Council who after the 1969 elections handed over power to the Busia led Progress Party ${ }^{7}$. He is credited with the good of having established the first Chieftaincy Act in 1961, which streamlined some of the powers of the chief.

The chief, today, is not as popular as he was years ago. However, his influence in governance and development remains seen. The legality of the chief is no longer solely based on custom or religion. Today, there is a need for the person nominated and elected as chief to have the name published in the national gazette. The process of gazetting is done to enable the chief perform statutory functions such as sitting on a judicial committee to adjudicate matters.

The court, for a long time, was divided as to the identity of the chief's office. Whereas it sought to bring the chief's office within the ambit of the law, it was not ready to discard its distinctively inborn customary nature.

\footnotetext{
${ }^{1}$ The 1992 Constitution provides for a criterion of people who cannot become chiefs. They include persons charged with having committed treason or high treason, endangering the state et cetera

${ }^{2}$ Brobbey and Others v Kwaku [1995-96] 1 GLR 125

${ }^{3}$ Boateng, Kwabena (2020). Chieftaincy: An Anachronistic Institution within a Democratic dispensation? The Case of a Traditional Political System in Ghana.

${ }^{4}$ K.A Busia, The Position of the Chief in the Modern Political system of Ashanti, (London: Oxford University Press, 1951)

${ }^{5}$ Asamoah, Kwame qualitative study of Chieftaincy and Local Government in Ghana. Journal of African Studies and Development Vol. 4(3), pp. 90-95, April 2012 Available online at http://www.academicjournals.org/JASD

${ }^{6}$ Supra note 1

${ }^{7}$ Denisova, Tatiana (2020) The role of Traditional leaders in the political life of West Africa: The Case of Ghana. The Evolution of Social Institutions.
} 
Contrary to the pre-colonial and colonial times, the advent of democracy raised questions to the identity of the chief's office. The Supreme Court settled the long-standing confusion in the case of Republic v High Court Registrar, Kumasi ex parte Yiadom" when it held that "Chieftaincy was not a public office and so it was not subject to quo warranto in the nature of an injunction". However, by virtue of Article 141 of the 1992 Constitution, Section 26 of Act $459^{2}$ and section 43 of Act $759^{3}$ - the High Court can quash by an order of certiorari or prohibition decisions and actions of chiefs on matters of fraud, breach of the rules of natural justice, and want and excess of jurisdiction as it was done in the case of Republic v Kumasi Traditional Council, ex parte Nana Opoku Agyeman $\mathrm{II}^{4}$.

\section{The Role of the Chief in the $21^{\text {st }}$ century}

The role of a Chief in modern day is drastically different from his role in pre-colonial times. He moves from being the Supreme overlord of a community to being an instrument of the colonial government. Today, they are merely struggling to remain relevant. The acts of the first government shortly after the attainment of independence were to weaken the power of Chiefs, yet the various essays, however, have suggested that they remain blatantly popular (Van de Walle, 2007) $)^{5}$. Despite the regression of the power of Chiefs in the $21^{\text {st }}$ century, their influence among their people remains standing and undisputed. The light of the chieftaincy institution was further rekindled in the life of Ghanaian people by the report issued in the Coussey Commission; "The whole institution of chieftaincy is so closely bounded with the life of our communities that its disappearance would spell a disaster. Chiefs and what they symbolize in the society are so vital that the subject of their future must be approached with greatest caution. No African of Gold Coast is without admiration for the best aspects of chieftaincy and all would loathe doing violence to it any more than social values embodied in the institution itself ${ }^{6}$ ",

The nature of the chief's office, as to whether he is a customary officer or public officer determines the roles he performs in his community. The role of a chief in this section would be classified into two; their customary duty and their legal duty.

\subsection{Customary role of the chief}

- Settlement of disputes: The chief till this day, acts as a mediator between his people and, his people and the gods. He, customarily, had jurisdiction in all matters and there was no right of appeal to his decisions. Though his decision-making power has been constitutionally limited, he remains an effective mediator of dispute between his people especially in civil matters ranging from land contestation, family dispute, robbery and stealing et cetera. Consistent with the studies of Boafo-Arthur (2003), customary courts are said to be popular among Ghanaians and often resorted to because they are easily accessible, inexpensive, speedy and relatable . $^{7}$.

- Ceremonial duties: The Chief in Ghana has duties similar to that of the Queen in England. He serves as a ceremonial figure and is responsible for the organization and celebration of festivals. He laisses with the government and other non-governmental institutions on behalf his community in public forums and meetings.

- Law-making: The law-making duty of the chief is said to be the only duty of the chief that could not be derogated from. The chief is responsible for making laws aimed at the development of the community. The laws made by the chief do not operate universally. These laws are subjective and vary from community to community depending on the prevailing custom and beliefs of the people in the community.

\subsection{Legal role of the Chief}

- Ensuring socio-economic growth: The chief is primarily responsible for the economic growth of the community. His duty to promote socio-economic growth means that he would initiate developmental projects in the community and negotiate with other traditional leaders to bargain for materials and resources. His duty also meant that he was responsible for mobilizing his members for community development. Wayo Seini (2006) argues that, though colonial and post-colonial times presented

\footnotetext{
1 (1986) JELR 66472 (SC)

${ }^{2}$ Courts Act, 1993 (Act 459)

${ }^{3}$ Chieftaincy Act, 2008 (Act 759)

${ }^{4}$ [1977] 1GLR $360 \mathrm{CA}$

${ }^{5}$ Nicolas Van de Walle, (2007), Chieftaincy in Ghana: Culture, Governance and Development. Foreign Affairs Newsletter.

${ }^{6}$ Joseph R.A Aryee "Some thoughts on the institutional representation of chiefs in the District Assembly and the Sub-District Structures" in Irene K. Odotei and A. Awedoba (Eds) Chieftaincy in Ghana: Culture, Governance and Development. (Accra: Sub-Saharan Publishers, 2006), p.57

7 Boafo-Arthur K (2003). "Chieftaincy in Ghana: challenges and prospects in the 21st Century.” Afr. Asian Stud., 2: $125-153$.
} 
different forms of government, it remained the duties of chiefs to ensure developments in their communities amidst the presence of the central government. ${ }^{1}$

- Liaise with the government on behalf of the members: The link between the government and the citizenry cannot be amicably actualized without the consented intervention of chiefs. The Ghanaian society is by its very nature indebted and unsavorily devoted to the chieftaincy institution, especially those members found in the under developed societies in Ghana.

- Codification of customary law and abolition of outdated laws: Chiefs function as mediating lynchpins between traditional custom and modern advancement (Van Dijk and Van Rouveroy van Nieuwaal, 1999). Being the custodian of the Ghanaian custom, they are empowered to adjust outdated and outlived traditional customs that do not habitat or drive at modern democracy or governance.

\section{Liabilities of a Chief}

Legal suits against a chief is popular in land law than any other area of law. He was customarily the custodian of all stool lands ${ }^{2}$. His interest over stool lands is like that of the trustee. The chief as laid down in Allotey $\boldsymbol{v}$ Abraham $^{3}$ is solely responsible for the management and alienation of stool property. The proceeds of such alienation are received by him as trustee for his subjects. Prior to the locus case of Gyamfi $\boldsymbol{v} \boldsymbol{O} \boldsymbol{w u s} \boldsymbol{u}^{4}$, an action could not be brought against a stool occupant nor could anyone, other than him, institute an action in respect of stool property. In 1991, the traditional immunity guaranteed chiefs against legal suits was cast down. The Supreme Court reversing the decision of the earlier court held in Owusu $\boldsymbol{v} \boldsymbol{A g y e i}^{5}$ that a chief can be held accountable in an action of fraud for stool land alienation and any money or proceed which might have been received by virtue of such alienation. Also, according to Article 275 of the 1992 Constitution 6 , "A person shall not be qualified as a Chief if he has been convicted for high treason, treason, high crime or for an offence involving the security of the state, fraud, dishonesty or moral turpitude." Under the law of tort, the chief like any other person is a walking tortious liability. He can sue and be sued under battery, assault, defamation, negligence and trespass.

\subsection{The Chief in Ghana's Politics}

The conceptualization of Chiefs as instruments of politicians is not a new concept. Over the last two decades or so, there has been a vile practice perpetuating in Ghana's politics where chiefs are being patronized by politicians to gain political advantage or solicit for votes. The first trace of this political game can be tracked to the era of indirect rule. For much of the $19^{\text {th }}$ century, British exercised its dominion over the people of Ghana through their chiefs. Indirect rule could be understood as the plan to use existing tribal structures and traditions as conduits for establishing rules and regulations, while British officers acted behind the scenes ${ }^{7}$. It was shortly after this era that, Dr. Kwame Nkrumah, was alleged to have mocked chiefs. His popular statement that, "only chiefs would run away and leave their sandals behind," was to the effect that chiefs had become pawns in the political arena ${ }^{8}$. During the tenure of his government, his acts were aimed at degrading the status and role of the chieftaincy institution. In fact, it has been suggested that if Nkrumah's government could not extinguish the chieftaincy institution then, nothing can destroy it. He and all the other nationalists existing at that time, had been revolted by the practice of the chiefs. They felt that the chiefs had turned their backs on their own people by allowing themselves to be used as instruments by the colonial administration to suppress the people through the imposition of unreasonable taxes and levies. These tax impositions increased the wealth of the colonial officers and chiefs while the Gold Coasters grew much poor.

The practice today is not so dissimilar from colonial times. The outstanding distinction lies in the fact that politicians are not trying to hide their diplomatic control over Chiefs. It is almost custom for politicians to solicit votes from natives through their chiefs. The British did same to gain popularity among the people. The Bond of 1844 as J.B. Danquah writes, did not give any new power to the British administration, it only recognized the defacto power they exercised over the various colonies through the chiefs. Christopher Pappoe ${ }^{9}$ reports that the

\footnotetext{
${ }^{1}$ Wayo Seini, "The role of traditional authorities in rural development", in Irene K. Odotei and A. Awedoba (Eds), Chieftaincy in Ghana: Culture, Governance and Development, (Accra: Sub-Saharan Publishers, 2006), p. 547

2 "stool land includes any land or interest in, or right over, any land controlled by a stool or skin, the head of a particular community or the captain of a company, for the benefit of the subjects of that stool or the members of that community or company. Article 295 of the 1992 Constitution

3 (1957) 320 WALR 308

4 (1980) JELR 66943 Court of Appeal

5 (1991) JELR 65081 Supreme Court

${ }^{6}$ ibid

${ }^{7}$ England's Indirect Rule in its African countries. American Historical Association. Available at https://www.historians.org/teaching-andlearning -in-the-digital-age/England's-indirect-rule-in-its-African-countries.

${ }^{8}$ Supra note 2

${ }^{9}$ Journalist of Volta Region's Radio Dela
} 
practice is not one-way streamed - "modern chiefs, as we have these days, are in better positions to lobby for their communities but they also stand in a more compromised position to be influenced by politicians. Many of such chiefs are big-time tycoon businessmen, who depend on government rapport to advance their businesses"1.

The rise in democracy and governance has also had a toll on the pockets of most chiefs. In order to keep their communities running, they must seek grants and aids from the government. These grants and aids usually come with political strings attached. Most of which are paid back by the chiefs offering their community support to these politicians and public officers upon a forth coming election. For some traditional rulers, they must swear allegiance to a particular government in order to be able to receive a reasonable portion of the national income for the maintenance of their towns. Sometimes, it seems that our chiefs' hands are tied up and forced into such agreements as it lays on their shoulder the responsibility of providing for their community.

Article 276(1) of the 1992 Constitution provides that,

"A chief shall not take part in active party politics; and any chief wishing to do so and seeking election to Parliament shall abdicate his stool or skin.”.

\subsection{What Article 276 implies}

The provision (supra) does not only seek to prohibit Chiefs from being subjects of active politics. It prevents them from also being used as objects of politics. Their role in politics, as far as the law is concerned, is to be neutral. Such neutrality is a question of fact and not of law. That is to say, they are not expected to do anything that would reasonably appear to a reasonable man that they are in favor of a particular political party or advancing the course of a particular political party.

\subsection{What Article 276 does not imply}

When Article 276(2) is read in conjunction with Article 94(3) (c) of the 1992 Constitution of Ghana, it is evident that the framers of the Constitution did not intend the provision to deny or restrict the political right of the chief as a "person", (which includes his right to vote, to form part of an association or to hold a political opinion), but to prevent him from actively engaging in politics. For this purpose, Article 276(2) of the 1992 Constitution states that;

(2) "Notwithstanding clause (1) of this article and paragraph (c) of clause (3) of Article 94 of this Constitution, a chief may be appointed to any public office for which he is otherwise qualified."

Article 94(3)(c) of the 1992 Constitution also states that;

(3) "A person shall not be eligible to be a member of Parliament if he is a chief."

\subsection{Acts amounting to "active politics" in Article 276}

The pivot of Article 276 is centered on "active politics" which is distinguished from "politics" and "partisan politics". As would be further elaborated, politics goes beyond a mode of governance or management of public affairs. It includes the livelihood of a group of people: what they eat, wear and drink. Thus, what a chief may wear, say or eat is politics. However, such kind of politics is not what the law is referring to in Article 276. The evolution of governance and advent of democracy also permits chiefs now, to become head of organizations and institutions. Such organizational and institutional positions occupied by chiefs cannot be construed to mean active politics within Article 276, although appointment to such positions may have political playouts. The term "partisan politics" on the other hand, is a form of politics where a chief's engagement in politics or exercise of his political right is evidently inclined towards a particular party. The pun of these terminologies is that though all partisan politics constitute active politics, not all active politics are considered to be partisan. An instance of partisan politics is seen in the clear support given by some chiefs towards a particular political party. In Ghana, the support of the Asantehene and Elmina chief towards the New Patriotic Party in the 2012 and 2016 election is a typical depiction of partisan politics. Partisan politics when engaged in by chiefs plays out as active politics.

What is active politics is a question of fact dependent on the special circumstance of each case. Active party politics is not defined within the laws of Ghana but it has been construed to mean the bearing of membership card, mounting of platforms for political campaign and an express declaration by a chief in support of a particular political party. An acclamation of a politician by a chief may not of its own constitute active partisan politics. Each of these circumstances is dependent on their own distinct proof based on evidence. Receiving of politicians by a chief during election period does not of itself constitute active politics. The reason being that, the chief is said to be a symbol of unity and oneness in a country. Thus, his counsel and home should be open to everyone seeking it. However, when such hospitality is protracted to only one political candidate and done in a manner so as to raise doubt to the neutrality of the chief, such an act would fall within active politics. When politics is partisan, it is clear and undisputedly constitutes active politics. As already stated, politics need not be

\footnotetext{
${ }^{1}$ As Ghana develops, chiefs' powers are being redefined. Retrieved from dw.com/en/as-as-ghana-develops-chief's-powers-are-beingredefined on October 9, 2021 at 9:57am
} 
partisan to be active. It could be active through certain acts of chiefs.

\subsection{Playout of chiefs in active politics}

A. CHIEFS BANNING POLITICAL PARTIES FROM THEIR COMMUNITY (year 2014, 2018, and 2019)

Quite regrettably, it has been the practice that some chiefs have publicly banned politicians and in extreme cases political parties from coming to their community. The reason for such banishment is usually the responsive effect of failed promises and alleged insults from such banned politicians. Such subversions have time and time again played out in Ghana's politics. In 2014, Nana Kofi Armah, the Krontihene of Dadieso in the Western Region banned the Deputy Chairman of the New Patriotic Party (NPP), Samuel Kofi Abiaw from the Western region for supposedly insulting the chiefs of the Western Region ${ }^{1}$. In 2018, the Asogli Traditional Council made up of 33 Volta Chiefs collectively banned the National Chairman for NPP, Mr. Freddie Blay not to step foot in the Volta Region. The ban follows from Mr. Blay's disrespectful comment made towards Togbe Afede XIV, the President of the Asogli Traditional Council (ATC) and his failure to apologize thereof. In a press release by The Ministry of Chieftaincy and Religious Affair, the Council on $15^{\text {th }}$ August 2018, stated that ;

a) "That Mr. Freddie Blay's cordial working relationship with the Council from now on has summarily become tainted;

b) That Mr. Freddie Blay's uncompromising attitude displayed will pave the way to mar his regional, zonal and grassroot engagements as Chairman of the NPP in the Region;

c) That Mr. Freddie Blay, should consider himself unwanted in the region, in particular, the Asogli Traditional Council Area, which will become for him a bitter experience, hereafter"2.

(A reproduction of part of the press release made by ATC in 2018)

The Ghanaian courts have made it clear that all political parties are entitled to equal right and opportunity to campaign and make known their policies and manifestoes. In case of New Patriotic Party $v$ Ghana Broadcasting Corporation $(\boldsymbol{G B C})^{3}$ where GBC sought to prevent NPP from reading out their manifesto on their platform, the Supreme Court held that GBC had acted illegally and breached the right of NPP. The court did also note that the right of a political party to present their policies and read their manifesto was a recognition and an act dependent on the right of the Ghanaian citizen to participate in politics which by implication, meant to be informed of the policies and agenda of a particular party to make an informed choice. In a more appropriate circumstance, the law does prescribe an appropriate way for people to express their dissatisfaction towards a particular government. It does not fall within the ambit of the chief to forbid a particular party their right to present their agenda to their community. Neither are chiefs empowered to direct their members on how to vote and who to vote for. Their involvement in politics through banning political parties impedes on the habitual practice of campaigning and making known their policies which is a front flag of politics and election.

\section{B. THREATENING OF PARLIAMENTARIANS BY CHIEFS IN THE DELIBERATION OF PROPOSED BILLS}

Quite recently, some chiefs in the turmoil of the anti-LGBTQ+ bill have issued severe threats against their parliamentary representatives. It is active politics within the meaning of Article 276(1) when a chief issues threats against the parliamentary representatives of their community so as to influence their decision on a national discourse. The Divisional Chief of Prestea Himan, Nana Nteboah Prah in October 2021 issued a strong warning against the Member of Parliament (Hon. William Kudjoe) of his area not to vote against the anti-lgbt bill. He states on the rainbow radio station that, "Let the word go out there that as a people, we are against LGBTQI+ activities. It is evil and against our values. We want our politicians to be categorical on the matter. But before that, we want our MP to understand that we as a people are against it. He should vote yes for the bill. If he finishes voting, he should show it to us so that we know if he voted YES or NO. If he votes against the bill, he should know that he is no longer with us in the coming election ${ }^{4}$ " The involvement of chiefs in national deliberation is becoming rampant. Although they may not on their own sit as members of parliament, it is repugnantly obvious that they exercise authority over those who hold such offices. It cannot be seen or heard anywhere that a country, in the pursuit of democracy, has chiefs who can dictate the decision a parliamentarian should take on national matters. Deliberations on national matters are purely questions of politics. Article 276 prohibits chiefs from involving themselves in such deliberations.

\footnotetext{
${ }^{1}$ Peace FM reports Chiefbans NPP Chair https://www.peacefmonline.com/pages/politics/201406/202588.php

${ }^{2}$ Daily Graphic(2018) https://www.graphic.com.gh/news/politics/volta-chiefs-ban-freddie-blay-from-entering-ewe-land.hmtl dated August 16, 2018. Retrieved October 22, 2021 at 9:10am

${ }^{3}$ [1993 -1994] 2 GLR 354- 393

${ }^{4}$ Do not vote against anti-lgbtqi+ bill- Divisional Chief of Prestea Himan to MP reported by rainbowradio.com on 0ctober, 15,2021 on ghanaweb.com/GhanaHomePage/ News archive retrieved on Friday, 22 ${ }^{\text {nd }}$ October 2021 at 6:54am
} 


\section{GOVERNMENT INTERFERENCE IN CHIEFTAINCY DISPUTES}

The Constitution mandates the National House of chiefs to be responsible for settling dispute on chieftaincy matters. However, the government has, in many situations, assumed the role of actors and mediators in many of these chieftaincy disputes. A report by (Bukari and Kufuor, 2021) ${ }^{1}$ depicted the recurring involvement of political parties in chieftaincy conflict through subtle support offered to the conflicting parties. Bukari (2021) makes foremost reference to the Bimbilla conflict involving two families of the same clan vying for the Nanun skin. He indicates that the New Patriotic Party support to the Gbomayili as well as, the National Democratic Congress support towards the Bangyili over the years did not go unnoticed. The Bawku conflict which ensued between the Kusasi and Mamprusi since 1951 according to (Bukari and Kufuor, 2021) lasted as long as it did because of the political involvement of the two largest political parties in Ghana, the New Patriotic Party and the National Democratic Congress.

Prior to the failure of successive governments and the traditional councils to resolve the Dagbon Chieftaincy dispute between the Abunu and Andani clan, a committee called the "Eminent Committee" chaired by the Asantehene Otumfuor Osei Tutu had been set up by the former President of the Republic of Ghana, President Kufuor in 2002 to provide roadmaps to solving the lasting dispute. It was, however, to no effect. Not until 2018 and more appropriately 2019, the interference of the President Nana Akufo-Addo through strengthening the volatile relationship of both parties brings an end to the decades-old Dagbon conflict. The relationship between chiefs and the government is a relationship interconnected to each other by the play of politics. Not only do chiefs get involved in active politics, the government also from time to time, gets involved in chieftaincy dispute through politics for national reasons.

\subsection{Why the need for Article 276?}

Conventionally, the words of a chief in decision making are final and binding. He had the final say in all deliberations and when he spoke, there was no appeal or review of his decisions. The rationale of modern politics is to ensure democratic deliberation. Democratic deliberation is the idea that all voices and views should be shared and weighed in order to come to a consensus on a matter. This would mean that no one's words could be held above the other. Such mode of deliberation would lead to an abominable practice where the words of the chief could be sidelined or disregarded. In 2014, the chiefs of Suaman District of the Western Region instructed the leaders of the New Patriotic Party "not to step foot in their palace ever again" upon disagreeing with the traditional leaders of the area on a national deliberation in the creation of a new district for the Suaman people ${ }^{2}$. It is in anticipation of such unpleasant situations by the framers of the constitution that chiefs were prohibited from engaging in active politics so that their power and decision may not be put to questioning in a deliberation, which is the idea of modern democracy.

The chief, as conceived in customary law, was the choice of the gods. He was the traditional mediator between his people and, his people and the gods. His fundamental duty was to ensure the protection of all his people and ensure that he handled the dispute among his people fairly and equally. On the line of fairness, he could not properly discharge his duties if he was affiliated to a political party. As a representative of the gods, he had to be impartial and neutral and, could not operate on the ticket of any political party. If that was not made the case, questions would be raised to the objectivity of his decisions.

At the time the 1992 Constitution of Ghana was drafted by the Consultative Assembly in $1991^{3}$, most chiefs were still regaining their power since Nkrumah's government and the various military regimes of $1966^{4}, 1972^{5}$, $1979^{6}$ and $1981^{7}$ had usurped these powers. Their control and influence in government and governance had been diminished. The quick gaining popularity of democracy in the early $19^{\text {th }}$ and $20^{\text {th }}$ centuries meant that there was a need for a more educated class of people to constitute government. Most of the traditional authorities at that time, had no formal education and had low literacy, their usefulness and contribution towards governance was put in question. Previous governments have always tried to draw a distinction between governance and custom as they have done between governance and religion. They believe that the tenets of governance could not be properly streamlined to the parameter of customs. The practice, therefore, has been that the officials should handle governmental issues whereas traditional authorities deal with matters of customs and traditions.

Also, chiefs not until now, were not very popular among the educated elites and early nationalists. Their

\footnotetext{
${ }^{1}$ Bukari, K., Osei-Kufuor, P., Bukari, S. (2021) Chieftaincy conflicts in Ghana are mixed up with politics: what's at risk. Available at https://theconversation.com/chieftaincy-in-Ghana-are-mixed-up-with-politics-what's-at-risk-166602

${ }^{2}$ Opoku (2014) Suaman Chiefs Ban NPP. Available at https://www.modernghana.com/news/545442/suaman-chiefs-ban.html . Retrieved October 22, 2021 at 9: $37 \mathrm{am}$.

${ }^{3}$ Consultative Assembly Law, 1991 (P.N.D.C.L 253)

${ }^{4}$ National Liberation Council, coup d'état of $24^{\text {th }}$ February 1966

${ }^{5}$ National Redemption Council Supreme Military Council coup d'état of $13^{\text {th }}$ January 1972

${ }^{6}$ Armed Forces Revolutionary Council coup d'état of $4^{\text {th }}$ June 1979

${ }^{7}$ Provisional National Defence Coup d'état of $31^{\text {st }}$ December 1981
} 
existence was a threat to the nationalist goal of achieving liberation of the masses. ${ }^{1}$ For the post-colonial governments, the chiefs as Rathbone (2000) asserted were a reminder of the influence of the colonial government on the Gold Coast colony. This was inferred from the fact that the British were readier to deal with the chiefs than with the educated elites. Regardless of all these events, the Ghanaian society remained devoted to their chiefs and their institution. The early nationalists were not ready to risk their opportunity to take over governance by involving chiefs in political administration of the country lest by so doing, they would grow unpopular in comparison to the chiefs.

\subsection{Plausibility of Article 276}

It would be very arduous if not impossible to disassociate traditional rulers from politics. Politics, as we know it, is beyond a mode of governance. It constitutes one's way of life. Politics refers to the political philosophy of a group of people, and when construed broadly includes what they eat, drink and wear. There is no absolute definition that can be assigned to politics. It is for this reason that Modebadze (2010) describes it as a "loaded term." As long as politics can be construed in such broad terms, removing the chief from active politics is same as disassociating him from his people.

It is also noted that it has been 30years since the 1992 Constitution was drafted. At the time the 1992 Constitution was drafted, there were only few educated chiefs. This being the case, the drafters of the 1992 Constitution did not contemplate the possibility of Ghanaian chiefs embracing foreign education so as to become stakeholders in modern politics. The 1991 government had hoped for a diplomatic and democratic mode of governance. This meant that there could be no room for the arbitrary power of the chief in such governance which would be regulated by politics. The disregard for their presence in politics was the way by which the framers of the 1992 Constitution could be sure that the government would be free from autocracy, being mindful of Nkrumah's government, the 1960 Constitution and its effect in the acclaimed case of $\boldsymbol{R e}$ - $\boldsymbol{A k o t o}^{3}$, along with the various military coups d'état that had taken place.

The role of the chief under both custom and statute is to ensure economic growth. There is a cohesive relationship between economic development and politics. Often at times, what is referred to as economic growth lapses with politics ${ }^{4}$. It becomes extremely difficult if not impossible, for a chief to carry out his role of promoting economic growth without engaging in some form of politics. The benchmark to measure effective political rule is through economic growth and development which includes an assessment of the development of the local communities and regions where the chief still acts as the paramount head. The government, in order to achieve this goal would be required to interact with the residing chief of the community in order to acquire his blessing and consent before there could be any land disposition or infrastructural development. In most cases, it is only upon lobbying by the government with the community chiefs are they able to mobilize the community members to get involved with the developmental project.

\section{The Canker of the Chieftaincy Institution}

Most part of the article sought to project the chieftaincy institution as a pawn of politics. However, to hold such an assumption would not only be erroneously wrong but also superficial. The chieftaincy institution particularly such as the one in Ghana is not without skeletons. Below is a discussion of some of the wrongs committed by the chieftaincy institution against Ghanaians.

Multiple Land Sale: A common practice among the chieftaincy institution in Ghana is for chiefs to dispose off the same land to two or more people. It is quite regrettable when information of chiefs trying to swindle their own subjects is uncovered to the public. These chiefs sell lands to their subjects, who receive it for a valuable consideration. When they notice that there has not been any development on the sold lands, resell them to other people without making any provision of compensation to the original buyer. The Law professor, Kwame Gyan on the Joy News show "Newsfile", hosted by Samson Lardy Anyenini converses the high risk associated with multiple sale under the dispensation of the new Land Act, 20205. The professor reiterates that, "chiefs can no longer randomly and wantonly dissipate lands like they used to do in the past. If you're [sic] the head of family, occupant of a skin, chief or head of a clan, you can no longer go on business as usual ${ }^{6 "}$

\footnotetext{
${ }^{1}$ ibid

${ }^{2}$ The definition of politics varies from time to time and from place to place. It has a wide range of meaning when used in everyday life. Politics is defined in such different ways as: the study of conflict resolutions, the art of government, the conduct and management of public affairs and so on. It has such narrow and broad construction which could include every aspect of the human life. Cited at the end note reference, number (5) of the Online Journal.

3 (1961) JELR 67633 (SC)

${ }^{4}$ Ibid (6)

${ }^{5}$ Section 9(2) of the Land Act, 2020 (Act 1036) states that, "chiefs, tendanas, clan heads, family heads or any other authority in charge of the management of stool or skin, clan or family lands, is a fiduciary charged with the obligation to discharge the management function for the benefit of the stool or skin, or clan or family concerned and is accountable as a fiduciary."

${ }^{6}$ Dzivenu, Emmanuel (2021) It's more dangerous for chiefs to sell land and pocket proceeds under new land law. Available at
} 
Personalizing communal funds: As part of their traditional role, they receive funds and revenues either from the government or individuals. As aforementioned, the chief in the discharge of his various responsibilities acts as a trustee of all his community members. Sometimes and quite unfortunately, these monies are received and used by the chiefs themselves for their personal enrichment.

Unwholesome government alliance: Some chiefs in the bid to secure a favorable stand in the political arena form alliance with a particular government. These alliances formed are grounded on the unwavering loyalty of the chief towards a particular political party. When the opposition party is put in power, instead of offering them their staunch support, they tally along the lines of partisan politics to thwart the efforts of the opposing government so as to make them unpopular in their community.

\section{Improvement towards Chieftaincy in Ghana}

Timothy Akpatsa ${ }^{1}$ well captures my resolution when he announces during his inauguration that, "one way to avoid this pitfall (in chieftaincy) is for traditional authorities to move away from the old ruling practice of partnering with politicians to secure their power, and instead partner with government and NGOs towards community development ${ }^{2}$

Assimeng (1981) also states that, "the influence of the chief so permeates the whole fabric of social life in the rural communities that if only a purposeful effort had been made to give it a modern outlook, chieftaincy would have played a more useful role in the life of the nation ${ }^{3}$." With the rise of educated chiefs in Ghana, which mind-you, were uncommon when Assimeng made this statement; indulging chiefs in modern democracy and re-evaluating their role in modern Ghana is not a bad way to promote good governance especially at the local level; not as tools in the hands of politicians but tool masters in their own right ${ }^{4}$.

\section{Conclusion}

Whereas, there may be a number of good reasons why the chief should not be involved in active politics. These reasons when compared with the plausibility of Article 276 are puny arguments. Although, I aver that the eminence of the chief should not be dwindled down to instruments of politicians; it is practically impossible to dissociate them from active politics.

The Chiefs are the original wielders of power and authority in the land. The chieftaincy institution is an eminent institution, though most of their powers had been whittled down by modern democracy. Our conscience and mind would not be innocent if we allow their dignity to be whittled down by the acts of ill-intentioned politicians. They are the representatives of gods and not of the President, representatives of the people and not of government. It is in them; the hopes and aspirations of the Ghanaian people are embedded. The framers of the Constitution desiring not to be accused of having denied the chiefs their fundamental human right to participate in politics provided in Article 276(1) of the 1992 Constitution of Ghana that whereas

"A chief shall not take part in active party politics; and any chief wishing to do so and seeking election to Parliament shall abdicate his stool or skin"

The goal of Article 276(1) is not to deny the chief his political right. I aver that the person of the chief and the office of the chief are all living entities. If a "person" desires to pursue his person then he cannot be the office. If he, however, pursues the office, then he cannot be his person. For the office on its own is a living person with his own right and, to pursue the office is to forsake the "person" and its rights- which is the right to actively participate in politics.

Also, their role as custodians of the land, rapporteurs with the government and agents of socio-economic growth and development could not effectively be performed outside the ambits of politics. As already mentioned, politics goes beyond la tete la tete and involves the entireness of the Ghanaian person. The balance to be drawn against these two competing interests is for Parliament to confer power on them; strong enough to make them self-sustaining of their community and weak enough not to make them dictators.

\section{ACKNOWLEDGEMENT}

When all is researched and written, the conclusion of the whole matter is, thanks be to God Almighty who causes us to succeed at all times and in all things. He is the everlasting God; the only true God. It is He that works in us both to will and to do of His good pleasure.

A discourse on chieftaincy would not be accurately articulated without the aid of a chief. They are truly an embodiment of knowledge and wisdom. Great thanks to Obrempon Hima-Dekyi XIV (Overlord of Dixcove)

\footnotetext{
https://www.myjoyonline.com , retrieved 14th October 2021 at 8:21pm.

${ }^{1}$ Paramount Chief of Fodome Traditional Area during his oath swearing

${ }^{2}$ ibid

${ }^{3}$ Assimeng M (1981). Social Structure of Ghana. Tema, Ghana Publishing Corporation.

${ }^{4}$ Their role in politics should be limited to only those which by custom they are required to do for the growth and development of their community.
} 
to whom I am grateful for the many calls we had, to put this article together and for gracing me with the blessing of writing down the foreword for my article.

Another big thanks to my friends Lydia Otchere, Emmanuella Allor-Annan and, Ernestina Kyere for tolerating my endless disturbances to complete my article. As much as I savored the pleasure of tormenting you with calls, your encouragement and constructive criticisms were well received.

\section{REFERENCES \\ Constitution}

Constitution of the Republic of Ghana, 1992. Accra, Ghana: National Legislative Bodies.

\section{Statutes}

Courts Act, 1993 (Act 459)

Chieftaincy Act, 2008 (Act 759)

Land Act, 2020 (Act 1036)

\section{The existing law}

Consultative Assembly Law, 1991 (P.N.D.C.L 253)

\section{Cases}

Allotey v Abraham (1957) 320 WALR 308

Brobbey and others v Kwaku [1995-96] 1 GLR 125

Gyamfi v Owusu (1980) JELR 66943 Court of Appeal

New Patriotic Party v Ghana Broadcasting Corporation [1993 -1994] 2 GLR 354- 393

Owusu v Agyei (1991) JELR 65081 Supreme Court

Re- Akoto (1961) JELR 67633 (SC)

Republic v Boateng ex parte Adu-Gyamfi II [1972] 1 GLR 317

Republic v High Court Registrar, Kumasi ex parte Yiadom (1986) JELR 66472 (SC)

Republic v Kumasi Traditional Council, ex parte Nana Opoku Agyeman II [1977] 1GLR 360 CA

\section{Books}

Arhin K (1985). Traditional Rule in Ghana: Past and Present. Accra, Sedco Publishing Assimeng M (1981). Social Structure of Ghana. Tema, Ghana Publishing Corporation.

K.A Busia, The Position of the Chief in the Modern Political system of Ashanti, (London: Oxford University Press, 1951)

Rathbone, "Kwame Nkrumah and the Chiefs: The Fate of Natural Rulers under Nationalist Governments", Transactions of the Royal Historical Society, vol 10, (2000): p. 45.

\section{Online Journals}

Asamoah, Kwame qualitative study of Chieftaincy and Local Government in Ghana. Journal of African Studies and Development Vol. 4(3), pp. 90-95, April 2012 Available online at http://www.academicjournals.org/JASD Boateng, Kwabena (2020). Chieftaincy: An Anachronistic Institution within a Democratic dispensation? The Case of a Traditional Political System in Ghana.

Boafo-Arthur K (2003). "Chieftaincy in Ghana: challenges and prospects in the 21st Century." African Asian Studies, 2: 125-153.

Denisova, Tatiana (2020) The role of Traditional leaders in the political life of West Africa: The Case of Ghana. The Evolution of Social Institutions.

Joseph R.A. Aryee "Some thoughts on the institutional representation of chiefs in the District Assembly and the Sub-District Structures" in Irene K. Odotei and A. Awedoba (Eds) Chieftaincy in Ghana: Culture, Governance and Development. (Accra: Sub-Saharan Publishers, 2006), p.57

Joseph K. Adjaye and Buba Misawa, "Chieftaincy at the confluence of Tradition: Transforming African Rulership in Ghana and Nigeria", International Third World Studies Journal and Review, vol 17, (2006): p. 1 Knierzinger, Johnson (2011) Chieftaincy and development in Ghana: From Political Intermediaries to Neotraditional Development Brokers. Department of Anthropology and African studies. Pp 6, 31-32

Modebadze, Valerie (2010): The term politics reconsidered in the light of recent theoretical developments, IBSU Scientific Journal (IBSUSJ) International Black Sea University, Tbilisi, Vol 4, p. 39

Nicolas Van de Walle, (2007), Chieftaincy in Ghana: Culture, Governance and Development. Foreign Affairs Newsletter.

Van Dijk and Van Rouveroy van Nieuwaal, EAB (1999) The domestication of chieftaincy in Africa: The imposed and the imagined. Africa Chieftaincy in a new socio-political landscape. 
Wayo Seini, "The role of traditional authorities in rural development", in Irene K. Odotei and A. Awedoba (Eds), Chieftaincy in Ghana: Culture, Governance and Development, (Accra: Sub-Saharan Publishers, 2006), p. 547

\section{Online Articles and sites}

A Shana develops, chiefs' powers are being redefined. Retrieved from dw.com/en/as-as-ghana-develops-chief'spowers-are-being-redefined on October 9, 2021 at 9:57am

Black's Law Dictionary, $2^{\text {nd }}$ Edition http://thelawdictionary.org/natural-person/

Bukari, K., Osei-Kufuor, P., Bukari, S. (2021) Chieftaincy conflicts in Ghana are mixed up with politics: what's at risk. Available at https://theconversation.com/chieftaincy-in-Ghana-are-mixed-up-with-politics-what's-at-risk166602. Retrieved October 22, 2021 at 10:10am.

Daily Graphic(2018) https:/www.graphic.com.gh/news/politics/volta-chiefs-ban-freddie-blay-from-enteringewe-land.hmtl dated August 16, 2018. Retrieved October 22, 2021 at 9:10am

Do not vote against anti-lgbtqi + bill- Divisional Chief of Prestea Himan to MP reported by rainbowradio.com on 0ctober, 15, 2021 at https://www.ghanaweb.com/GhanaHomePage/NewsArchive/Do-not-vote-against-anti LGBTQ+bill-Divisional-Chief-of-Prestea-Himan-to-MP-1380700 retrieved on Friday, 22 ${ }^{\text {nd }}$ October 2021 at 6:54am

Dzivenu, Emmanuel (2021) It's more dangerous for chiefs to sell land and pocket proceeds under new land law. Available at https://www.myjoyonline.com , retrieved 14th October 2021 at 8:21pm

England's Indirect Rule in its African countries. American Historical Association. Available at https://www.historians.org/teaching-and-learning-in-the-digital-age/England's-indirect-rule-in-its-Africancountries.

Opoku, Emmanuel (2014) Suaman Chiefs Ban NPP. Available at

https://www.modernghana.com/news/545442/suaman-chiefs-ban.html. Retrieved October 22, 2021 at 9: $37 \mathrm{am}$.

\section{Online Report}

Canada: Immigration and Refugee Board of Canada, Ghana: Information on the Chieftaincy process and how people are destooled and enstooled by whom, and whether the government gets involved, 1 May 1994, GHA17145, available at https://www.refworld.org/docid/3ae6ad8a2f html [accessed 6 October 2021].

\section{Speeches and Radio broadcast}

Christian Pappoe, journalist of Volta Region's Radio Dela

Paramount Chief of Fodome Traditional Area, Timothy Akpatsa during his oath swearing

Citi News report on "Drobo chiefs threaten to campaign against Jaman South MP if he does not support the antiLGBTQI bill” at https://youtu.be/ywdWgXRKLWk by Michael Sampong Efum.

Peace FM reports https://www.peacefmonline.com/pages/politics/201406/202588.php Chief bans NPP Chairman. Retrieved October 22, 2021. 